\title{
THE CASE OF IMMIGRANT PARENTS IN RAISING THEIR MULTILINGUAL
} CHILDREN

Ersika Puspita Dani ${ }^{1}$, Friska Yanti Simaremare ${ }^{2}$

${ }^{1}$ STMIK Pelita Nusantara

${ }^{2}$ Institut Teknologi dan Bisnis Indonesia

Corresponding Author: Author’s Name, Ersika Puspita Dani E-mail: ersikapuspitadani@ gmail.com

ARTICLE INFO ABSTRACT

Received: 2020-02-24

Accepted: 2020-03-16

Published: 2020-03-15

Volume: 4

Issue: 1

DOI:

https://doi.org/10.33019/lire.v

$3 \mathrm{i} 2.67$

KEYWORDS

parent's style, multilingual, children
This qualitative research investigated real events in the case of immigrant parents in raising their multilingual children. This research focused on finding out what kinds of the parenting style to make their children multilingual, how the processes occurred, and what the language problems during the multilingual children process were. In conducting this research, it was taken from some information from questioner and interview directly and indirectly whose data were collected based on the children ability in multilingual, the differences of parents' education and origin background to be analyzed. There were three findings, namely 1) there are two styles of parenting applied by 8 parents, involves: 7 parents applied the authoritative parenting styles in which their parents applied the combination of demandingness and responsiveness, and 1 parents applied authoritarian style in raising their multilingual children demandingly and unresponsively, (2) There are many processes that are done by parents in raising their multilingual children. Dominantly, multilingual children have used to learn multilingual languages from their parents and environments, their parents always familiarize themselves to always be able to adjust in social, cultural, habits, geographical residence, and so on, which is always supported by the situations, and conditions occurred at that time. (3) There are only two kids are found to have a problem, namely dyslexia and code switching.

\section{INTRODUCTION}

Language is a basic need for every human being. Humans need language to express what they want to convey. Everyone has at least master one language to survive in their environment, her/ his own mother tongue or gesture language.

In this modern time, having the ability to speak more than one language is very important. Many factors such as finding work in a more developed country, joining a family in a new country, studying abroad or even communicating with a partner from another country requires one to speak other foreign language. Thus, these factors intentionally or unintentionally make many people are shaped as multilingual. Nowadays, the most important influencing social trends are somewhat

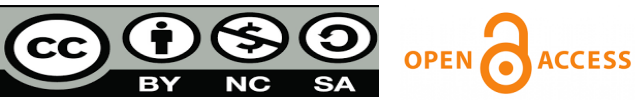

This work is licensed under Creative Commons Attribution-ShareAlike 4.0 Internasional.

Copyright (C) 2020, Ersika P. D., \& Eriska Y. S. 
different: we can mention the influence of migration, language policies, globalization and internationalization, increased recognition of minority rights, and education to influence multilingualism (see Blackledge \& Creese, 2010; Edwards, 2012; Weber \& Horner, 2012). Also Aronin and Singleton (2012) underline the importance of globalization regarding its effect on multilingualism in our modern world.

Not only adults, children have also been formed in such a way by their parents to be multilingual. In fact, parents compete to want their children to be multilingual. Even many of them who do not care about the huge costs that has to be spent in order to raise multilingual kids. This is a concern about the importance of growing up being multilingual. So with these demands, many public especially private schools or course have foreign language program class. This proves that the need to speak more than one, or more language, is in great demand.

To make it comes true, it needs a work of people around. The family, especially parents, is the foundation of success or failure in the child's achievement in language learning. Parents are very important. Parents', teachers' and students' beliefs are extremely important, since they can contribute to conversations about the status of a foreign language. Then, this will have an impact on language policy decisions and on a new direction for multilingual education, (Griva \& Chostelidou, 2011; Nespor, 1987). In addition, the family also plays an important role in promoting their children's positive thinking towards foreign languages. The success of their children in improving their multilingual competence is influenced by parental attitudes; both the parents' way in perceiving the foreign language and in behaving the linguistic development of their children (Young, 1994).

It has a lot of facilities and support for shaping multilingual kids nowadays. However, in reality, it is not as easy as people think practically to achieve it. According to Worp (2016) the term multilingualism seems to be rather easy to define. The search of the term "multilingual" usually leads to simple definitions such as "able to speak more than two languages" (Collins dictionary, 2016), "speaking or using several different languages" (Oxford dictionary, nd) or "speaking, written in, or using several different languages "(Cambridge dictionary, 2016). However, in practice it is a much more complicated question than what these definitions might show.

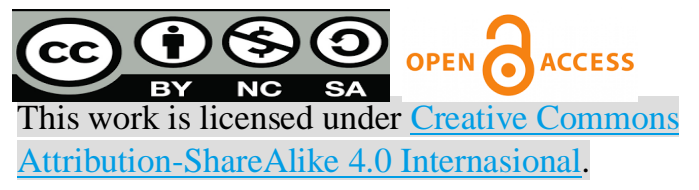

Copyright @ 2020, Ersika P. D., \& Eriska Y. S. 
THE CASE OF IMMIGRANT PARENTS IN RAISING THEIR MULTILINGUAL CHILDREN

Lire Journal (Journal of Linguistics and Literature) P-ISSN: 2598-1803 E-ISSN: 2581-2130 Volume 4 Number 1 March 2020

This research is about parenting style in raising multilingual children. It is fascinating to be further examined due to its existence as one of the examples that parenting style is fun and tolerable do in the process of making of making their multilingual. It is also necessary to discuss how the process and whether there are language problems during the process of raising multilingual children. Therefore, the purpose of this study is to find out what kinds of the parenting style to make their children multilingual are, how the processes are, and what the language problems during the multilingual childcare process are.

\section{LITERATURE REVIEW}

Parents are the most important human for their children's life. Every parent has her/his own style to shape the children. All things related to the achievement of the children mostly influenced by the action or role of the parents.

As stated by Morrison (1978) that parenting is a process in developing and utilizing the children's skill and knowledge. It is not an easy task. It becomes a challenging task considering the emergence of the different family structures stemming from the socio-economic and cultural changes, which over time has caused a rise a number family of blended, single parent, partnership and foster families (Dailey, Krause \& Pacey, 2009). Related to this fact, Sanagavarapu (2010) quoted from Wise and Silva (2007) writing that parenting is a process in giving interaction between values, attitude, practice, discourse and the way in raising their children in each culture.

In addition, Dailey et.al (2009) confirmed that the core principle in parenting is same in all of societies; it is basically a way in ensuring the physical and psychological well-being of their children. Then, parents basically mold their children into adults through the influence world (Baumrind, 1971).

\subsection{Parenting Styles}

As stated by Baumrind (1971), he identified there are three styles in parenting: (1) Authoritative, is combination of demandingness and responsiveness in which the parents make a logical demand, set limit, and insist on children's compliance, whereas at the same time, they are warm, can accept the children's points of view, and can encourage the children's participation. In the other words, 66

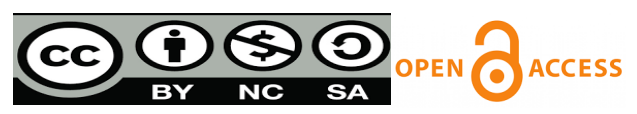

This work is licensed under Creative Commons Attribution-ShareAlike 4.0 Internasional. 
this parent is always supportive although they always monitors and disciplines fairly. (2) Authoritarian, is demanding and unresponsive in which the parents only give a lack of response to their children without any questions. This type will become a power assertive technique of socialization used by authoritarian parents and retrain children's self-independence and expression. (3) Permissive, is a style that give a freedom highly and do not restrain their attitude, and it is an approach for socialization between responsive and undemanding. In this case, sometimes the parents avoid imposing although they accept the children's attitude.

Therefore, it can be concluded that the parenting styles have an essential influences towards the children's achievements because it has a strong relationship between parenting styles and the academic achievements of children.

\subsection{Multilingual}

It is not allien anymore for people to talk about multilingualism. Multilingualism can be seen arise years lately as it becomes the basic needs for some people. Lewis (2009) stated that this is to be expected, considering that there are almost 7,000 languages in the world and about 200 independent countries. It means that an individual is in a big potential to learn more than one language, or even more.

Based on the Aronin \& Singleton (2008), multilingualism is often assumed to two or more languages. Then, De Groot (2011) stated that some researchers always use the bilingual term for two languages and multilingual for three or more. Li (2008: 4) defined a multilingual individual as "anyone who can communicate in more than one language, be it active (through speaking and writing) or passive (through listening and reading". Braun (1937: 115) defines multilingualism as “active vollendete Gleichbeherrschung zweier oder mehrerer Sprachen” (“active, completely equal mastery of two or more languages"). He also points out, that this is more a theoretical concept than a natural practice. While Fishman (1980) already made this useful distinction between bilingualism or multilingualism as an individual phenomenon and as a societal phenomenon. Multilingualism is not only seen as an individual characteristic, but also as something pertinent to a community. Individual multilingualism refers to the competences of an individual to communicate in two or 67

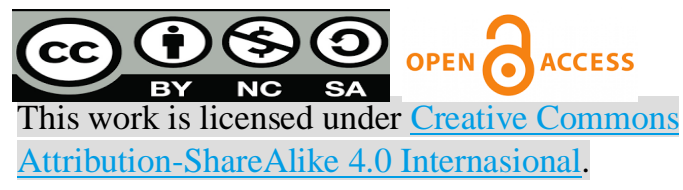

Copyright @ 2020, Ersika P. D., \& Eriska Y. S. 
THE CASE OF IMMIGRANT PARENTS IN RAISING THEIR MULTILINGUAL CHILDREN

Lire Journal (Journal of Linguistics and Literature) P-ISSN: 2598-1803 E-ISSN: 2581-2130 Volume 4 Number 1 March 2020

more languages whereas social multilingualism refers to the use of two or more languages in society (see also Cenoz \& Gorter, 2012; Edwards, 1995). Furthermore, Franceschini (2009: 34) stated that multilingualism is a product of the fundamental human ability to communicate in a number of languages. What really defines the difference between bilingual and multilingual, is first of all the clear quantitative distinction, as bilingualism seems to exclusively refer to two languages and multilingualism to more than two (Aronin \& Hufeisen; 2009; Cenoz, 2013).

There are many factors to shape an individual become multilingualism. Aronin and Singleton (2008) compared that the historical features and multilingualism, these give seven distinctions, which can be clustered into three main areas. They are geographical, social, and medium.

Multilingual speaker uses a language as resource in communicating. In this case, they usually have more suitable resources than monolingual speakers. As stated by Cenoz (2013), multilingual speakers either use different languages in isolation or mixed related to their communicative needs and their interlocutors. Meanwhile, monolingual speakers only used one language in each situation, for instance, a multilingual person can read newspaper in one language but a report of technical in another language, he also cab chat in two languages in the internet depends on the interlocutors, but when he watched film, he just focused on one language.

\subsection{Language Problems towards Multilingual Speaker}

\subsubsection{Code Switching}

People who have different culture with their living environment probably experience a code switching. As stated by Kim (2006), that it is common for bilingual societies in using a language and do switch to the others in their conversation. Then, Zentella (1985) said that code switching has several function, such as to hide their fluency and memory problems in their conversation, to mark switching from the informal to formal situations, to control especially for parents and children, and to align the speaker to the others in specific situation.

In addition, Poplack (1980) mentioned that code switching can be categorized into three types. Firstly is tag switching which includes the tag insertion in the sentence form, from one language to another. Secondly, intersentetial code switching, is kind of switching in a clause or sentence

68

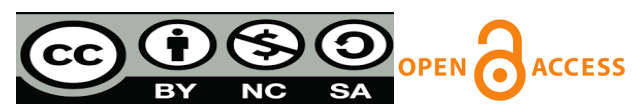

This work is licensed under Creative Commons Attribution-ShareAlike 4.0 Internasional.

Copyright @ 2020, Ersika P. D., \& Eriska Y. S. 
level. Finally, intrasentential code switching, involves a switch within sentence or clause and it may include mix within the boundaries of word.

\subsubsection{Dyslexia}

The word Dyslexia is comes from Greek Origin, which begins with a prefix means impaired. Dyslexia person get a problem in their development. In this case, they get decrease in the process of written word, involves spoken and written one. Meanwhile, their understanding in verbal is avoided. When they learn the words from reading they can usually understand the materials.

Berninger, Abbott, Thomson \& Raskind (2001) stated that there are three markers measure, are not oral reading or written spelling per se but tend to impair in dyslexics, such as phonological coding, orthographic coding, and rapid automatic naming (RAN).

\section{METHODOLOGY}

This research adopted the qualitative research method. According to Saldana (2011) Qualitative Research refers to a broad range of research methods for the study of a natural social phenomenon whose data is collected and analyzed through non-quantitative means.

To taking the sample of this research, it used random sampling technique which is done by choosing the multilingual children which can speak three or more language, the differences in the education background of their parents, namely primary school, junior high school, senior high school, bachelor degree, master degree, and doctoral, and the differences in the parent's origin, namely France, Indonesia, Netherland, Bosnia and Herzegovina, Italy, Slovenia, Malay, English, Minang, and Singapore. Therefore, there were eight children has been chosen randomly and it was selected as the sample of the research.

Basically, it is a research whose findings are derived from real world events. To get the data, it had been gathered from the textual materials such as questioner and interview transcripts which are done directly and indirectly (by using email and social media). The data which has been gathered from the transcript of interview were analyzed through interactive model of Bogdan and Biklen (1982: 145). It was analyzed by doing some steps, namely (1) Organizing and breaking the data 69

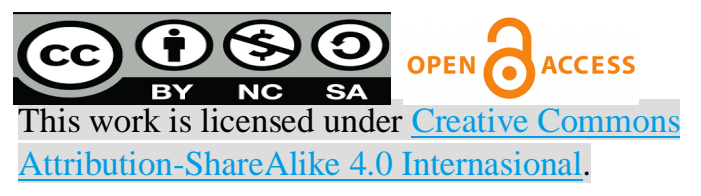

Copyright (C 2020, Ersika P. D., \& Eriska Y. S. 
THE CASE OF IMMIGRANT PARENTS IN RAISING THEIR MULTILINGUAL CHILDREN

Lire Journal (Journal of Linguistics and Literature) P-ISSN: 2598-1803 E-ISSN: 2581-2130 Volume 4 Number 1 March 2020

into manageable units. In this case, the data which have been transcribed would be put in the table by coding the names of the participants. (2) Synthesizing the data. In this case, the data would be categorized based on the parent's education, parents origin and children ability in multilingual, (3) Searching for the parents' style in raising their children multilingual and discovering what was important and what was to be learned to would be displayed in the findings into an easily understood explanation, and (4) Deciding what will be told others. In this case, this study would give the conclusion.

\section{RESULTS AND DISCUSSION}

\subsection{Kind of the Parenting Style is Applied in raising the Multilingual Children}

Theoretically, there are three parenting styles such as authoritative, authoritarian, and permissive with these concepts of responsiveness and demandingness in mind (Baumrind, 1971). The data found that from total eight (8) parents, there are seven (7) parents applied the authoritative parenting styles, while another one (1) parents used authoritarian style in raising their multilingual children.

\subsection{The Process of Raising the Multilingual Children}

The following are the data of each respondent:

\section{Student A}

In her 10 years old, she speaks four languages, such as France, Indonesian, English and Minang language. Her father is from France, while mother from Indonesia. To master France language, her father initially speaks France from her earliest age and commitment until now. Her father's big family always speaks France to her not only when she visits them but also by phone call routinely. Her parents give a routine schedule to take their child to France. Now even she lives in Indonesia, she has a France neighbor and always speaks France to them.

She is capable to speak Indonesia because of mother. In her earlier age, mother speaks Indonesian language to her. She lives in Indonesia most of her lifetime, so she has big opportunity to practice Indonesian language. Her mother's big family really helps her to update her Indonesian language.

70

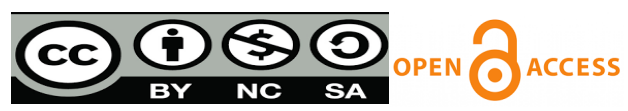

This work is licensed under Creative Commons Attribution-ShareAlike 4.0 Internasional. 
She starts learning English officially when she is in 7 years old. It is the first time for her to study in International school with English as instructional language. At the beginning, she does not understand much, but in two years, she manages it well.

The fourth language she speaks is Minang language. She has a routine schedule to visit Padang city, Indonesia, her grandmother's house, where all people speaks Minang. In a year, she visits Padang at least four times. In every visit, she takes surfing course with Minangnese language as the instructional language.

\section{Student B}

She is 11 years old and master English, Malay and Slovenia language. Her father is from Slovenia and her mother from Singapore. She lives in Singapore, and most people use English. However, she masters English because she initially exposed with English from her earlier age. Her parents speak English to each other. Her parents speak English to her too. From her baby age, mother always give her English story books for her. She studies in school with English as an instructional language.

Understanding the Malay language, she gets from mother. Mother starts speaking Malay to her when she masters her English. Mother's big family, who also lives in Singapore, always speaks Malay to her. At her school, there is few lessons in Malay language.

In learning Slovenian language, she gets it during her living in Slovenia for two years. She attends the Slovenian course for two years. It is exactly when she is 6 . Since that, father always tries to speak some Slovenian language to her. Parents takes her to visit Slovenia routinely, and all father's big family always speak Slovenian to her.

\section{Student C}

This student speaks four languages, English, Indonesia, France and Bosnian in his 14 years old. His parents come from Indonesia. His mother initially exposes him to English language. She always speaks English from her earlier age to his two years old. He goes to International kindergarden and English as instructional language in Dubai. He has experience to study in Billingual school, where 50\% language instructional is English. In addition, he is a game addicted child, where to play the game, he only communicate with English.

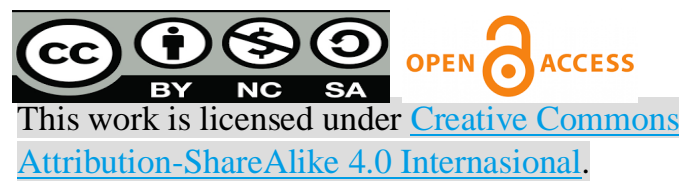

Copyright (C 2020, Ersika P. D., \& Eriska Y. S. 
THE CASE OF IMMIGRANT PARENTS IN RAISING THEIR MULTILINGUAL CHILDREN

Lire Journal (Journal of Linguistics and Literature) P-ISSN: 2598-1803 E-ISSN: 2581-2130 Volume 4 Number 1 March 2020

Actually, this student does not have any experience before in France language. Since he lives in Sarajevo, and parents enroll him to a France school. In this school, France is the only as instructional language. Therefore, he gets the France skill language from his school. She studies from age 10 to 14 .

In daily conversation with some friends in her school makes him able to speak Bosnian. Mother, who is also a learner of one Bosnian course, sometimes practices Bosnian language to him.

\section{Student D}

At 9, student D speaks three languages, Netherland, English and Bosnian. His parents are Spanish. He learns his first language, Netherland, when he lives in Netherland from early age to four years old. His mother and all mothers' big families speak Netherland to him. He also studies at Kindergarden School where Netherland is the instructional language.

When at four years, he and his family move to Bosnia and Herzegovina. He lives in his grandparent's house, where all of the family speaks Bosnian. He starts to learn Bosnia language. He studies in government school and Bosnian language is the only language for instructional language.

The skill of English language he gets mostly from mother. Mother always guides him to speak English. She makes routine schedule to watch English movie. Every night or in spare time, mother always accompany him to finish his English homework. Most of the time, she plays an English song and asks her son to sing together. Mother believes songs can both increase vocabulary and pronunciation English skills. His father has also contribution. From baby to now, father speaks English to his friends and student D always listens.

\section{Student E}

This student speaks Italian, Indonesian and English language exactly when she is 11 years old. She gets the Italian language skills from her father and father's family. Since baby, she lives in Italy and all the family (especially father) speaks Italian all the time.

On the other hand, mother always speak Indonesian language to her from his very early age. At the same time, sometimes mother speaks English too to her. However, mother speaks Indonesian

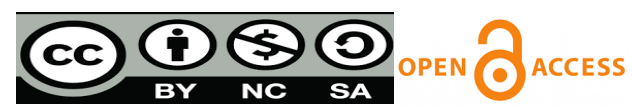

This work is licensed under Creative Commons Attribution-ShareAlike 4.0 Internasional. 
language $75 \%$ and $25 \%$ for English language. There is a small problem happened to this student but finally mother can overcome it soon.

At 3, her family bring her to America to live there. Her father gets job in America. It means student E has more chance to speak English more than another two Italian and Indonesian language.

\section{Student F}

At 9, this boy speaks four languages, such as Spanish, English, France and Bosnian. He gets his Spanish language skill from his family when he lives in Spain. He lives in Spain for some years. His grandparents and all family speak Spain to him. In addition, he studies in Kinder garden School with Spain as an instructional language.

From baby, mother always speak English to him. Mother has intention to make him as a multilingual kid. At kinder garden School, he studies English subject for some hours a week. Mother always gives him an English book from his early age, far before his school age. Every night or in spare time, mother always help to teach him English, or to help to finish his English homework.

He speaks France from 5 years old, and he gets it from his school. Since 5, he and his family move to Bosnia and Herzegovina. Mother put him to France school, where France is the only language as instructional language. Until now, at 9, he can speak fluently France.

He also speaks Bosnian since he lives in Bosnia. Some friends and neighbor speak Bosnian language to him, which makes him to force himself to speak Bosnian too. Mother also teaches him to speak Bosnian.

\section{Student G}

Student G speaks Indonesian, Mandarin, English and Hokkien at 9 years old. Her parents are both Chinese. This student lives in Indonesia, and Indonesian language is his first language. In Bilingual school, she has chance to speak about 30\% Indonesian language.

This student speaks Mandarin fluently. Mother starts to speak Mandarin since her earliest age to now. Mother has intention to make her kid to be able to speak Mandarin like her. Mother stimulates her kid to Mandarin language from baby with giving baby books. She gives storybooks in Mandarin routinely. This student always listen her parents speak Mandarin. In addition, from 73

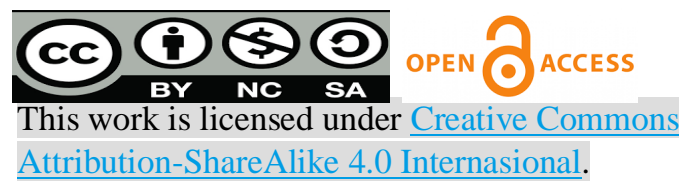

Copyright (C 2020, Ersika P. D., \& Eriska Y. S. 
THE CASE OF IMMIGRANT PARENTS IN RAISING THEIR MULTILINGUAL CHILDREN

Lire Journal (Journal of Linguistics and Literature) P-ISSN: 2598-1803 E-ISSN: 2581-2130 Volume 4 Number 1 March 2020

kinder garden to junior high school level, she studies in Bilingual school, where Mandarin as instructional language for almost 30\%. A big family from father also speaks Mandarin to her most of the time.

She speaks English too. She gets English skill from his school too, especially when in kinder garden school where English is the majority as an instructional language. Mother always guides her too in English language. Since baby, mother always buys baby books to her. Mother also put her to an English course from early age.

Almost all the mother's big family speaks Hokkien language. She is often to meet mother's family, which makes her common with Hokkien language. When mother meets her friends, mother always speak Hokkien, and mother always takes her kid to be with her. It means student $\mathrm{G}$ has experience to listen and see people's conversation in Hokkien language. Mostly student's G environment like neighbor and friends around house speak Hokkien to her daily.

\section{Student H}

Student G speaks Indonesian, Sundanese, Bosnian and English language at her 9 years old. She speaks Indonesian, as it is her mother's tongue. Her parents come from Indonesia. From earlier age, she is arounded by people who speak Indonesian language. Her mother speaks Indonesian about $50 \%$ to her, while the rest speaks Sundanese. She is also common and adapted with people who speak Sundanese. She lives in West Java where mostly people speak both Indonesian and Sundanese. Therefore, she is master of Indonesian and Sundanese from her earlier age.

At 4, her parents bring her to Bosnia and Herzegovina. Her mother enrolls her to a public school in Sarajevo and the only instructional language at that school is Bosnian language. The schoolmates, teachers and people around the school bring her to the capability of speaking Bosnian language. She does not need long time to understand Bosnian language. Now she speaks Bosnian language fluently.

She grabs the English language because there is an English subject at her school in Bosnia. She speaks English to her neighborhood. During in Bosnia, her father mostly speaks English to her, to help her in mastering English language. Now at 9, she speaks English very well.

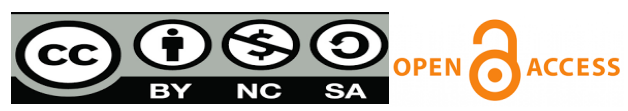

This work is licensed under Creative Commons Attribution-ShareAlike 4.0 Internasional. 


\subsection{Language Problems during the Process of Raising Multilingual Children}

It is common that children have difficulty or even big problems during the process of raising the multilingual children. However, in this research, there are only two kids are found to have a problem, namely dyslexia and code switching.

\subsubsection{Dyslexia Problem}

Students A get a problem with dyslexia. The core feature of dyslexia, consistently and systematically found in case studies and study groups, even when compared to controls with same reading skill levels, is the deficit of phonological awareness and on the phonological route of reading (Bugliotti, Serniclaes, Messaound- Galusi\& Charolles, 2008) defines phonological awareness as the capacity of thinking over the sound elements that make up words. The phonological route is characterized by the segmented decoding of words, through the graphemephoneme conversion. There is a large body of evidence that the domain of the relationship between graphemes and phonemes is crucial to successfully learn reading and writing. The main evidences are based on longitudinal studies that found that individuals later diagnosed as dyslexic performed low in phonological awareness, even before starting the process of acquiring reading and writing skills. Then, the studies investigated the efficacy of training based on the grapheme-phoneme correspondence and it showed that dyslexics have serious difficulty of reading without assistance of the lexical knowledge (reading pseudo-words) (Bogliotti et al, 2008).

At 7, student A has dyslexia problems. She speaks France and Indonesian very well. However, when she must speak English at her school, she has problem. At the beginning of lesson, she can manage it. However, after raising the problem, months and months, she cannot write and read well. She does not know how to write well, and even very slowly. It is the same like writing; she cannot read as fast as her friends at the school. Especially when teacher gives assignment of reading passage, she does not know to do that. There is no any idea for her what to conclude after reading. Even, when the examination day, she just make her answer sheet no answer at all, or empty. This is often she does during the examination.

Since that, teacher then speaks to her mother. Mother immediately checks her to the doctor. Finally, doctor says that student A has dyslexia problem. Then, her mother gives many treatments 75

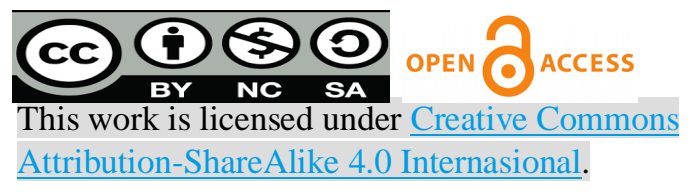

Copyright (C 2020, Ersika P. D., \& Eriska Y. S. 
THE CASE OF IMMIGRANT PARENTS IN RAISING THEIR MULTILINGUAL CHILDREN

Lire Journal (Journal of Linguistics and Literature) P-ISSN: 2598-1803 E-ISSN: 2581-2130 Volume 4 Number 1 March 2020

as best as she can. Mother helps her to read and write every night. After going home from school, mother takes her to a private course in reading and writing class. In addition, mother gives her everyday some organic vitamins to help her healthy.

In two years, exactly at age of 9, student $\mathrm{A}$ has no more problems with dyslexia. She can read and write very well. Even she gets much better than the expectation. She is the fastest student in the classroom for the subject of reading passage.

\subsubsection{Code Switching Problem}

There are various definitions of code switching. Kachru (1978) in Gardner-Chloros makes a distinction between code switching, code mixing and odd mixing. The first category is where 'the change is determined by the function, the situation and the participants', code-mixing is where linguistic units are transferred between codes, and odd mixing covers the instances of language mixing that do not fit the other two.

McClure (1977) and Blom \& Gumperz (1972) describe code mixing as a linguistic behavior where one code is dominant and elements of the other code are assimilated into the base code. This is different from borrowing, since borrowing is a monolingual practice and mixing is bilingual intra group behavior. McClure \& McClure (1975) and Wentz \& McClure (1977) use the term code switching as the general term to describe the phenomenon. This term covers both code mixing and code changing. Code mixing occurs in sentences that belong to L1, or have $\mathrm{Ll}$ as the base language, and within constituent boundaries, and code changing occur between constituent boundaries and results in sentences that are sequentially L1 and L2. Code mixing is used because the L2 word or expression is better known than its equivalent in L1, and code changing is used more for effect, as a stylistic device.

Student E gets code- switching problem when she is at 2 years old. She likes to switch language when she speaks. When mother speaks Indonesian language, she replies with Italian. When grandmother speaks Italian, she replies her with Indonesian language. In this case, mother immediately manages her with giving more practices. Mother always leads her and guides her to whom she must speak Italian and Indonesian.

76

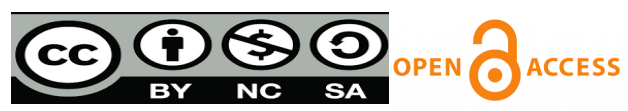

This work is licensed under Creative Commons Attribution-ShareAlike 4.0 Internasional.

Copyright @ 2020, Ersika P. D., \& Eriska Y. S. 
Actually, before that age, she is able to speak Indonesian language to her mother and Italian language to his father and her father's family. It means, when mother asks her in Indonesian language, she replies well with Indonesian language too. In addition, when her father speaks in Italian language, she can answer in Italian language. In addition, she is also speaking English passively.

Exactly at age 3, her parents bring her to Seattle, America. At that age, mother enrolls her to a preschool which English is an instructional language. The problem rises. Student E cannot follow the lessons in the classroom. Even when teacher speaks in English, she replies with Italian or Indonesian language. According to teacher, it is a big problem for the kid, as this influences her lesson capability in the classroom.

Since that, mother stops to speak Indonesian language to her. Mother tries to guide her every day and every night. She intensively helps her kid to work on her exercise books from school. Father also gives support by speaking with her in English language.

Only for a month, she can speak English very well. She can accept the lesson from school, and no more code switching anymore. Mother then back to speak Indonesian language to her. Father also speaks Italian back to her.

\section{CONCLUSION}

After analyzing this study, it, it can be concluded that (1) There are two styles of parenting which is applied by 8 parents, involves: 7 parents applied the authoritative parenting styles, and 1 parents applied authoritarian style in raising their multilingual children. (2) There are many processes that are done by parents in raising their multilingual children. Dominantly, multilingual children have used to learn multilingual languages from their parents and environments. In this case, they are used to learn multilingual language since early stage from any cases. In addition, their parents always familiarize themselves to always be able to adjust in social, cultural, habits, geographical residence, and so on, which is always supported by the situations, and conditions occurred at that time. (3) There are only two kids are found to have a problem, namely dyslexia and code switching. Based on the conclusions stated above, this study has some suggestions to the readers as provided,

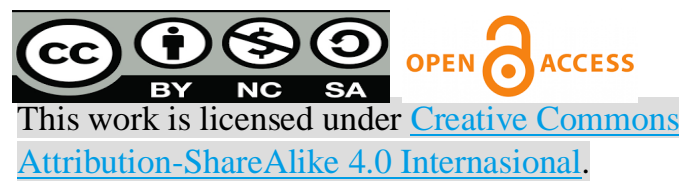

Copyright (C 2020, Ersika P. D., \& Eriska Y. S. 
THE CASE OF IMMIGRANT PARENTS IN RAISING THEIR MULTILINGUAL CHILDREN

Lire Journal (Journal of Linguistics and Literature) P-ISSN: 2598-1803 E-ISSN: 2581-2130 Volume 4 Number 1 March 2020

namely (1) to the other researchers, it is suggested that this study could be further expanded, elaborated and explored in other field in order to contribute the development of multilingual in other application or literary works, and (2) to all the readers, it is suggested to use the study as references for understanding the parent's style in raising the children multilingual.

\section{ABOUT THE AUTHOR(S)}

The authors are a lecturer of STMIK Pelita Nusantara and Institut Teknologi dan Bisnis. 


\section{REFERENCES}

Aronin, L., \& Hufeisen, B. (2008). The Exploration of Multilingualism. Development of Research on 13, Multilingualism and Multiple Language Acquisition. Amsterdam / Philadelphia: John Benjamins Publishing Company.

Aronin, L., \& Singleton, D. (2012). Multilingualism. Amsterdam / Philadelphia: John Benjamins Publishing Company.

Blackledge, A., \& Creese, A. (2010). Multilingualism: A Critical Perspective. London: Continuum.

Baumrind, D. (1991). The Influence of Parenting Style on Adolescent Competence and Substance Use. Journal of Early Adolescence. 11 (1), 56-95.

Baumrind, D. (1996). The discipline controversy revisited. Family Relations, 45, 405-414.

Braun, M. (1937). Beobachtungen zur Frage der Mehrsprachigkeit. Göttingische Gelehrte Anzeigen, 4, 115-130.

Cambridge Dictionary (2016). Cambridge dictionaries online. Retrieved from http://dictionary.cambridge.org/es/diccionario/inglesespanol/multilingual

Cenoz, J., \& Gorter D. (2012). Hacia un horizonte multilingüe. In E. Alcón, \& F. Michavila (Eds.), La Universidad Multilingüe (pp. 131-149). Madrid: Editorial Tecnos.

Cenoz, J. (2013). Defining multilingualism. Annual Review of Applied Linguistics. 33, 3-18. doi:10.1017/S026719051300007X

Collins Dictionary (2016). English dictionary. Retrieved from http://www.collinsdictionary.com/dictionary/english/multilingual

Dailey, Tahlia, M., Krause, Pacey, H. (2009). Handbook of Parenting: Styles, Stresses and Strategies. Nova Science Publishers.

Edwards, J. (1995). Multilingualism. England: Penguin Books.

Edwards, J. (2012). Multilingualism: Understanding Linguistic Diversity. London: Continuum.

Fishman, J.A. (1980). Bilingualism and Biculturism as Individual and as Societal Phenomena. Journal of Multilingual \& Multicultural Development, 1(1), 3-15. doi:10.1080/01434632.1980.9993995

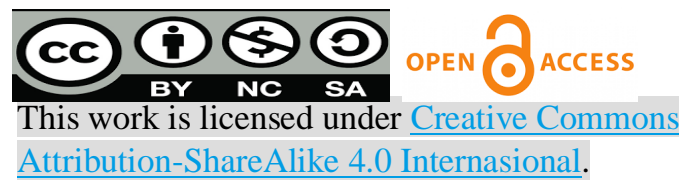

Copyright (C 2020, Ersika P. D., \& Eriska Y. S. 
THE CASE OF IMMIGRANT PARENTS IN RAISING THEIR MULTILINGUAL CHILDREN

Lire Journal (Journal of Linguistics and Literature) P-ISSN: 2598-1803 E-ISSN: 2581-2130 Volume 4 Number 1 March 2020

Griva, E., \& Chostelidou, D. (2011). Multilingual Competence Development in the Greek Educational System: FL teachers' beliefs and attitudes. International journal of multilingualism, 1-15.Multilingual matters.

Kim, E. (2006). Reasons and Motivations for Code-Mixing and Code-Switching. Spring 2006 Issues in EFL Vol.4 No.1 , 43-61.

Oxford Dictionary. (n.d.). Oxford dictionary. Retrieved from http://www.oxfordlearnersdictionaries.com/definition/english/multilingual? $q=$ multilingual

Poplack, S. (1980). Sometimes I'll Start a Sentence in Spanish Termino En Espanol: Toward a Typology of Code-Switching. 581-618.

Pratiwi, D. (2009). Users' Reasons for Multilingual Code Switching on Facebook Status. Bandung: Unpublished Paper UPI

Saldana, J. (2011). Fundamentals of Qualitative Research. New York, Oxford University Press.

Sanagavarapu, P. (2010). What does cultural globalization mean for parenting in immigrant families in the 21st Century. Australian Journal of Early childhood. Vol 35 (2) P. 36-42.

Weber, J. J., \& Horner, K. (2012). Introducing Multilingualism: A Social Approach. London/New York: Routledge.

Young, A. S. (1994). Motivational State and Process within the Socio-Linguistic Context. Birmingham: Aston University.

80

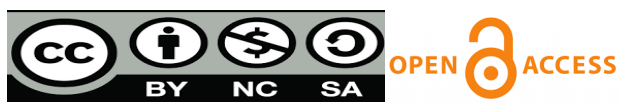

This work is licensed under Creative Commons Attribution-ShareAlike 4.0 Internasional.

Copyright (C) 2020, Ersika P. D., \& Eriska Y. S. 